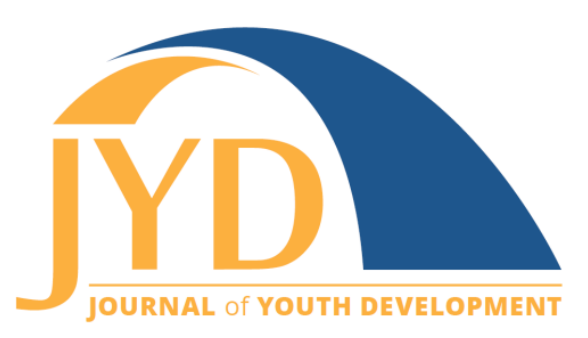

http://jyd. pitt. edu/ | Vol. 14 Issue 4 DOI 10.5195/jyd.2019.829 | ISSN 2325-4017 (online)

\title{
Does Gender Minority Professional Experience Impact Employment Discrimination? Two Résumé Experiments
}

\author{
Ashley N. Cabacungan \\ Department of Health Education and Promotion, East Carolina University \\ ashley.cabacungan@duke.edu \\ Joseph G. L. Lee \\ Department of Health Education and Promotion, East Carolina University \\ leejose14@ecu.edu

\section{Beth H. Chaney} \\ Department of Health Education and Promotion, East Carolina University \\ chaneye@ecu.edu
}

\section{Paige E. Averett}

School of Social Work, East Carolina University

averettp@ecu.edu

\begin{abstract}
We sought to examine perceived gender identity, perceived co-worker discomfort, and salary recommendations for youth counselors with transgender-related work experience. In two experiments conducted in 2016 and 2017, we randomized participants to view 1 of 2 résumés with varying work experience at a camp for transgender youth or a generic youth camp. Study 1 participants were 274 adult festivalgoers at a lesbian, gay, bisexual, and transgender pride festival. Study 2 participants were 296 employed, heterosexual adults aged 35-60 from an online survey panel. In Study 1, viewing the résumé with transgender experience resulted in a statistically significantly higher likelihood of reporting the applicant was gender minority than cisgender (adjusted odds ratio $=3.76,95 \%$ confidence interval $[1.32,10.72], \mathrm{p}=.01$ ), higher but not a statistically significant level of co-worker discomfort (aOR $=$ $1.39,95 \%$ CI $[0.83,2.32], \mathrm{p}=.22)$, and, although not statistically significant, a $\$ 2,605$ higher salary (95\% CI [-\$604, - \$5,814], p = .11). In Study 2, we found a statistically significantly greater likelihood of reporting the applicant was gender minority than cisgender $(\mathrm{OR}=2.56,95 \% C I[1.36,4.82], \mathrm{p}<.01)$, statistically significantly higher odds of reported co-worker discomfort (OR $=3.57,95 \%$ CI [2.15, 5.92], p
\end{abstract}

(cc) EY New articles in this journal are licensed under a Creative Commons Attribution 4.0 License. This journal is published by the University Library System, University of Pittsburgh and is cosponsored by the University of Pittsburgh Press. The Journal of Youth Development is the official peer-reviewed publication of the National Association of Extension 4-H Agents and the National AfterSchool Association. 


\section{Courtesy Stigma for Counselors}

$<.01)$, and, although not statistically significant, a \$1,374 higher salary $(95 \%$ CI [-\$1,931, \$4,679], $\mathrm{p}=$ .41). Our results indicate the potential for stigma by association for professionals working with marginalized groups and suggest potential pathways through which employment discrimination may exacerbate existing inequities for gender minority people.

Key words: social discrimination, gender identity, employment, job application, personnel selection

Youth and young adult camp counselors gain experience and skills that can positively impact their life and employment (Digby \& Ferrari, 2007; Duerden et al., 2014; Garst, Franz, Baughman, Smith, \& Peters, 2009). Counselors may be drawn to camp counseling to learn more about youth development, build work experience, and because of their own experiences (DeGraaf \& Glover, 2003). Some counselors, like other health and human services practitioners, have been drawn to the field to help address problems in their own communities (e.g., Bemak \& Chung, 2005; Fouad, Gerstein, \& Toporek, 2006; Lekus, 2001; Mail \& Lear, 2006; Teich, 2019). There are increasing numbers of summer camp experiences designed specifically for sexual and gender minorities (SGM; e.g., lesbian, gay, bisexual, and transgender people) both nationally, such as Brave Trails (Gillig, Miller, \& Cox, 2019), Camp Aranu'tiq (Teich, 2019), Queer Oriented Radical Days of Summer (QORDS, 2019), and internationally (Fenton, 2018; Malek, Harrison, \& John-Baptiste, 2017; Vincke \& van Heeringen, 2004).

Camps for SGM youth can have positive impacts on campers (Gillig et al., 2019; Vincke \& van Heeringen, 2004), but can working for camps associated with stigmatized groups come at a professional cost to camp counselors? This paper seeks to explore that question, recognizing that regardless of the answer, such work is important. Indeed, understanding the impact of professional experience associated with a stigmatized group can inform future work to ameliorate and overcome consequences.

Stigma, which we define to include the association of negative stereotypes with an identity and resulting status loss and discrimination (Goffman, 1986; Link \& Phelan, 2001), is well documented for SGM people (James et al., 2016; Meyer, 2003). Resulting discrimination is linked to poorer health outcomes (Fredriksen-Goldsen et al., 2014; Institute of Medicine, 2011) and can negatively influence camp experiences (Gillard, Buzuvis, \& Bialeschki, 2014). We focus here on gender minority (GM; e.g., transgender) adults, as growing national acceptance of SGM people has been stymied by recent policy decisions rescinding inclusion of GM people (Green, Benner, \& Pear, 2018). A small literature documents that GM adults face employment discrimination (Bardales, 2013; James et al., 2016; Make the Road New York, 2010; Rainey \& Imse, 2015). Existing literature indicates stigmatization of GM identities is related to negative 


\section{Courtesy Stigma for Counselors}

perceptions about hiring GM employees compared to cisgender employees, even when they are equally qualified (White Hughto, Reisner, \& Pachankis, 2015).

Less explored is the role of employment discrimination against people who work professionally in a gender-minority serving organization, regardless of whether or not they identify as transgender themselves (e.g., cisgender people working in transgender advocacy groups, as counselors at GM-serving youth camps, etc.). A literature on stigma-by-association or "courtesy stigma" has provided some exploration of this (Bos, Pryor, Reeder, \& Stutterheim, 2013). Stigma-by-association is the devaluation or stigmatization of a person based on their association with a marginalized individual or group (Goffman, 1986; Kulik, Bainbridge, \& Cregan, 2008).

Stigma-by-association is most likely to occur when an individual holds negative attitudes towards the marginalized individual and when their associate voluntarily chooses to interact with the marginalized individual (Kulik et al., 2008). Historically, stigma-by-association has been documented in multiple studies across associates of various stigmatized groups (Hebl \& Mannix, 2003; Phillips, Benoit, Hallgrimsdottir, \& Vallance, 2012; Sack, Seidler, \& Thomas, 1976), including associates of gay and lesbian communities (Goldstein, 2017; Neuberg, Smith, Hoffman, \& Russell, 1994; Sigelman, Howell, Cornell, Cutright, \& Dewey, 1991; Swim, Ferguson, \& Hyers, 1999). Discrimination by association has important implications for the professional well-being of health and human services professionals, regardless of their actual identities.

Several perspectives can explain stigma-by-association. In one approach from interpersonal psychology, individuals may be motivated to stigmatize the associates of marginalized individuals to maintain cognitive consistency or balance (Heider, 1958; Sigelman et al., 1991): Balance theory suggests that if person (A) favors person (B) and both person (A) and person (B) dislike person $(C)$, cognitive consistency or balance is maintained among person (A). However, if person (B) favors person (C), who is disliked by person (A), cognitive inconsistency or imbalance is generated within person (A). In an effort to restore cognitive balance, person (A) may perceive similarities between person (B) and person (C) and may develop negative perceptions (i.e., stigmatize) person (B), who they initially favored. Balance theory has previously been applied to the stigmatization of heterosexuals who associate with gay men (Neuberg et al., 1994; Sigelman et al., 1991). Alternatively, individuals may assume associates of stigmatized individuals are indeed members of the stigmatized group themselves. They also may avoid people who interact with "deviant" individuals or groups for fear of being assigned to 


\section{Courtesy Stigma for Counselors}

the same stigmatized group (Gurwitz \& Marcus, 1978; Sigelman et al., 1991; Swim et al., 1999).

Although the literature on stigma-by-association for GM people is limited, previous studies around sexual orientation hypothesized heterosexuals may avoid interacting with gay and lesbian individuals in fear of being perceived as gay or lesbian (Buck, Plant, Ratcliff, Zielaskowski, \& Boerner, 2013; Gurwitz \& Marcus, 1978). For example, in one experimental study (Sigelman et al., 1991), participants who expressed strong intolerance of gay men perceived heterosexual college students who voluntary chose to share a dorm room with a gay student as possessing the same stereotyped characteristics assigned to gay men. These participants also reported liking the voluntary roommate of a gay student less than heterosexual students involuntarily rooming with a gay student and those rooming with another heterosexual student.

We undertook this research to deepen understanding of employment discrimination against GM adults and potential stigma-by-association spillover. To that end, we studied employment discrimination among job applicants with transgender-related employment history at a summer camp and explored whether the nature of their employment history impacted (a) perceptions about their gender identity, (b) coworker discomfort, and (c) recommended salary. We hypothesized that résumés showing transgender-related employment history would (a) increase perceptions about GM status, (b) increase coworker discomfort, and (c) decrease recommended salary.

\section{Methods}

\section{Study Design}

We studied the role of transgender-related work experience utilizing two experimental résumé studies. Since gender identity discrimination may occur even within SGM communities, we conducted Study 1 at an SGM community festival in Durham, NC. In Study 2, the same survey was conducted among an online panel of employed heterosexual, cisgender adults aged 35-60. In both studies, we utilized a randomized experimental design and approach previously reported by Pedulla (2014). The studies were approved by the East Carolina University and Medical Center Institutional Review Board. 


\section{Courtesy Stigma for Counselors}

\section{The Résumé}

In each study, participants were randomly assigned the experimental or control résumé; each participant viewed only one résumé. Transgender-related work experience was signaled using a summer camp for transgender youth ("Camp Aranu'tiq for Transgender \& Gender Variant Youth"). The control was a summer camp with no gender identity affiliation ("Camp Birch Hill"). With exception of the summer camps, all information included on the experimental and control résumés was identical. To decrease the likelihood of sex-based discrimination (male/female) confounding the analysis, the same gender-neutral name ("Taylor Anderson") was utilized on both résumés. Addresses were changed to be from North Carolina. Résumés are otherwise the same as in Pedulla's 2014 study. Each participant received the same set of survey instructions that were previously published in the Pedulla (2014) study:

Please imagine that your friend, who runs a large retail store, is in the process of hiring someone for an assistant manager position. He has asked you to help him with the hiring process by reviewing one of the résumés he received for the position. . . . After you have thoroughly reviewed this résumé, please move to the next screen and respond to the questions that follow with your first, uncensored impressions (p. 83).

\section{Study 1}

\section{Study Population and Recruitment}

In Study 1, the survey experiment was conducted on September 24, 2016, at an LGBT community festival in Durham, NC. English-speaking adults, 18 years and older, were eligible to participate in the survey. Trained research assistants recruited participants using convenience sampling by approaching festival goers to participate in the survey as they walked by the research tent on festival grounds. A \$5 gift card was offered as an incentive for participating in the survey. The survey was provided on an iPad using the Qualtrics offline survey app. The survey included other topics and one other experiment about health messages (that appeared after the résumé experiment).

\section{Perceived Gender Identity}

To assess the relationship between transgender-related work experience and perceived gender identity, we asked participants to report the gender identity (i.e., "cisgender," "transgender," or 


\section{Courtesy Stigma for Counselors}

"don't know/don't remember") of the job applicant they reviewed at the end of the survey. The terms cisgender and transgender were defined for participants.

\section{Assessment of Informal Employment Discrimination}

To assess informal employment discrimination, we modified an approach used by Pedulla (2014) to measure the perceived likelihood that the job applicant would make co-workers feel uncomfortable by asking: "Please rate how much you are worried the applicant would make coworkers feel uncomfortable." Response options ranged from "not at all" (1) to "very much" (4).

\section{Assessment of Formal Employment Discrimination}

In Study 1, we assessed formal employment discrimination by measuring differences in salary recommendations based on the presence or absence of transgender-related work experience included on the résumés. After participants were provided with the survey instructions and reviewed the job applicant's résumé, following Pedulla (2014) they were asked to recommend an annual salary for the applicant: "What annual salary would you recommend for this candidate?" [open text].

\section{Study 2}

\section{Study Population and Recruitment}

In Study 2, the experiment was conducted online January 27 to February 3, 2017. Participants were recruited by Qualtrics Panels. English-speaking adults in the United States who were employed, between the ages of 35 and 60 years, and who reported a straight or heterosexual sexual orientation and a cisgender gender identity were eligible to participate. Qualtrics provided participant incentives in the form of points. Measures of perceived gender identity, informal discrimination, and formal discrimination were identical to Study 1. Of note, Study 2 was shorter than Study 1 as it did not contain other experiments or topics.

\section{Analysis}

Following Pedulla (2014), we limited salary recommendations to those of $\$ 10,000$ to $\$ 80,000$. We assessed randomization in both studies using Pearson Chi-Square and Fisher exact tests. Due to an imbalance of LGB-identified individuals in Study 1, we adjusted for sexual orientation and sex assigned at birth as covariates in Study 1 . Results were not sensitive to the inclusion of these covariates. We used multinomial regression with a cisgender reference category for 


\section{Courtesy Stigma for Counselors}

perceived gender identity. We utilized generalized linear regression for the ranked perceived coworker discomfort dependent variable. We assessed the appropriateness of ordinal regression using a test of parallel lines. We used ordinary least squares linear regression for the salary recommendations. We coded the experimental transgender-related work experience to make the control résumé the reference category. We tested for interactions between study and (a) perceived gender identity and (b) salary recommendation. All analyses were conducted in SPSS 24. There were few missing data points; we used pairwise deletion. We set alpha at 0.05 and used two-tailed tests.

\section{Results}

\section{Study 1}

\section{Participant Sociodemographic Characteristics}

In Study 1, 274 participants completed the survey and provided valid salary recommendations. Among the 274 participants in Study 1, participants' mean age was 35.2 years ( $S D=14.1$ ), over half were employed for wages (58\%) and most self-reported their race as White $(80 \%)$. The majority of participants were cisgender $(94.6 \%)$, while $0.7 \%$ and $4.4 \%$ identified as transgender or other gender, respectively. Over half of participants reported their sexual orientation as gay or lesbian (54\%), $16 \%$ reported being bisexual and $29 \%$ reported their sexual orientation as heterosexual (Table 1).

Table 1. Characteristics of Participants in Two Résumé Studies

\begin{tabular}{|c|c|c|}
\hline & $\begin{array}{l}\text { Study } 1 \\
\text { frequency* }(\%) \\
(n=274)\end{array}$ & $\begin{array}{l}\text { Study } 2 \\
\text { frequency* }(\%) \\
(n=296)\end{array}$ \\
\hline \multicolumn{3}{|c|}{ Gender assigned on birth certificate } \\
\hline Male & $121(44.2 \%)$ & $145(49.0 \%)$ \\
\hline Female & $151(55.1 \%)$ & $151(51.0 \%)$ \\
\hline \multicolumn{3}{|l|}{ Gender identity } \\
\hline Male & $118(43.1 \%)$ & $145(49.0 \%)$ \\
\hline Female & $141(51.5 \%)$ & $151(51.0 \%)$ \\
\hline Transgender & $2(0.7 \%)$ & - \\
\hline Other & $12(4.4 \%)$ & - \\
\hline
\end{tabular}


Table 1 (continued)

\begin{tabular}{|c|c|c|}
\hline & $\begin{array}{l}\text { Study } 1 \\
\text { frequency* (\%) } \\
(n=274)\end{array}$ & $\begin{array}{l}\text { Study } 2 \\
\text { frequency* }(\%) \\
(n=296)\end{array}$ \\
\hline \multicolumn{3}{|c|}{ Ethnicity: Hispanic/Latino/Spanish origin } \\
\hline Yes & $27(9.9 \%)$ & $30(10.1 \%)$ \\
\hline No & $244(89.1 \%)$ & $266(89.9 \%)$ \\
\hline \multicolumn{3}{|l|}{ Racet } \\
\hline White & $219(79.9 \%)$ & $258(87.2 \%)$ \\
\hline Black or African American & $40(14.6 \%)$ & $24(8.1 \%)$ \\
\hline American Indian or Alaskan Native & $10(3.6 \%)$ & $4(1.4 \%)$ \\
\hline Asian & $10(3.6 \%)$ & $6(2.0 \%)$ \\
\hline Native Hawaiian or Pacific Islander & $1(0.4 \%)$ & $0(0.0 \%)$ \\
\hline Other & $8(2.9 \%)$ & $8(2.7 \%)$ \\
\hline \multicolumn{3}{|l|}{ Sexual orientation } \\
\hline Gay or Lesbian & $148(54 \%)$ & - \\
\hline Bisexual & $44(16 \%)$ & - \\
\hline Heterosexual & $80(29 \%)$ & $296(100 \%)$ \\
\hline \multicolumn{3}{|l|}{ Employment Status } \\
\hline Employed for wages & $160(58.4 \%)$ & $296(100 \%)$ \\
\hline Self-employed & $16(5.8 \%)$ & - \\
\hline Out of work for 1 year or more & $3(1.1 \%)$ & - \\
\hline Out of work for less than 1 year & $11(4.0 \%)$ & - \\
\hline Homemaker & $4(1.5 \%)$ & - \\
\hline Student & $60(21.9 \%)$ & - \\
\hline Retired & $15(5.5 \%)$ & - \\
\hline Unable to work & $5(1.8 \%)$ & - \\
\hline Age & Mean (SD) & Mean (SD) \\
\hline Years & $35.24(14.12)$ & $45.53(7.35)$ \\
\hline
\end{tabular}

Note. Study 1 participants were a convenience sample of attendees at a 2016 LGBT community festival in Durham, North Carolina. Study 2 participants were recruited by Qualtrics panels in 2017 from employed heterosexual adults in the United States, aged 35 to 60.

*Frequencies do not sum due to sporadic missing values.

tTotals sum to over $100 \%$ due to the selection of multiple options. 


\section{Courtesy Stigma for Counselors}

\section{Perceived Gender Identity}

Although most participants reported they "did not know/did not remember" the gender identity of the résumé they reviewed (74.7\%), seeing the résumé with transgender work experience was statistically significantly associated with thinking the applicant was transgender, $a O R=$ 3.76 (95\% CI $[1.32,10.72], p=.01)$ compared to thinking they were cisgender. Of participants who saw the résumé with transgender work experience, $20 \%$ reported the applicant was transgender compared to $6 \%$ of participants viewing the control résumé.

\section{Informal Employment Discrimination: Co-Worker Discomfort}

Perceived co-worker discomfort ranged from 1 (not at all) to 4 (very much) $(M=1.47, S D=$ 0.79 ) in Study 1. Participants assigned the résumé that indicated transgender-related employment history a higher but not statistically significant level of co-worker discomfort (aOR $=1.39,95 \% \mathrm{CI}[0.83,2.32], p=.22)$ than for the résumé without transgender-related employment history. The same pattern of results was found when restricting to only respondents who reported an applicant had a gender identity that matched the work experience of the résumé they viewed $(a O R=1.65,95 \% \mathrm{CI}[0.44,6.26], p=.46)$.

\section{Formal Employment Discrimination: Salary Recommendation}

The average salary recommendation was $\$ 41,686$ (SD = \$13,281). Participants at the LGBT festival assigned the résumé with transgender-related work experience an average salary $\$ 2,605$ higher than the average salary assigned to the résumé without transgender-related experience (95\% CI $[-\$ 604, \$ 5,814], p=.11)$, which did not reach the threshold of statistical significance. The same pattern of results was present when restricting to only those respondents $(n=44)$ who reported an applicant had a gender identity that matched the work experience of the résumé they viewed: $\mathrm{A} \$ 1,373$ higher salary $(95 \% \mathrm{CI}[-\$ 5,841, \$ 8,588], p=$ .70), which also did not reach the threshold of statistical significance.

\section{Study 2}

\section{Participant Sociodemographic Characteristics}

Of the 296 participants in Study 2, respondents' mean age was 45.5 (SD=7.4) years. Most self-reported their race as White (87.2\%), and all were employed for wages, cisgender and reported their sexual orientation as straight or heterosexual (Table 1). 


\section{Courtesy Stigma for Counselors}

\section{Perceived Gender Identity}

Again although many participants reported they "did not know/did not remember" the gender identity of the résumé they reviewed (44\%), seeing the résumé with transgender work experience was statistically significantly associated with thinking the applicant was transgender $(O R=2.56,95 \% \mathrm{CI}[1.36,4.82], p<.01)$, compared to thinking they were cisgender. Of participants who saw the résumé with transgender work experience, $41 \%$ reported the applicant was transgender compared to $22 \%$ of participants viewing the control résumé. A test for moderation by study did not show a statistically significant interaction, $p=.67$.

\section{Informal Employment Discrimination: Co-Worker Discomfort}

The résumé including transgender-related work history resulted in statistically significantly higher odds of higher reported co-worker discomfort ( $O R=3.57,95 \% \mathrm{CI}[2.15,5.92], p<$ $.01)$. This pattern was similar when restricting to only the respondents $(n=102)$ who reported an applicant had a gender identity that matched the work experience of the résumé they viewed $(O R=6.51,95 \%$ CI $[2.41,17.59], p<.01)$.

\section{Formal Employment Discrimination: Salary Recommendation}

In Study 2, 296 participants completed the survey and provided valid salary recommendations. The average salary recommendation was $\$ 41,795(S D=\$ 14,436)$. Participants in the online panel of employed heterosexual, cisgender adults assigned the résumé listing transgenderrelated work experience a $\$ 1,374$ higher salary (95\% CI $[-\$ 1,931, \$ 4,679], p=.41)$, which did not reach the threshold of statistical significance. The pattern for those participants who reported an applicant had a gender identity that matched the work experience of the résumé they viewed was similar $(\$ 2,543,95 \%$ CI $[-\$ 3,194, \$ 8,279], p=.38)$, which did not reach the threshold of statistical significance. A test for moderation by study did not show a statistically significant interaction, $p=.85$.

\section{Discussion}

\section{Principal Findings}

Regarding our three hypotheses, both of our studies supported our hypothesis that listing transgender-related work experience increases the likelihood that the person reviewing the résumé will consider the applicant transgender. Both studies showed higher perceived coworker discomfort, although only the study conducted among employed, straight adults reached the 


\section{Courtesy Stigma for Counselors}

traditional threshold of statistical significance. Finally, neither study's results supported our hypothesis about salary discrimination. Instead, effects for salary did not meet thresholds for statistical significance and were in the opposite direction of those hypothesized. These findings suggest that a substantial proportion of reviewers link identity with work experience and that workplace discrimination may operate through more informal/interpersonal pathways than salary recommendations. Additionally, our salary recommendations, while not reaching traditional statistical significance, may suggest a positive effect on salary that deserves further exploration. One possible reason may be that work with SM populations indicates more specialized work experience and experience with diverse populations that could be valued by employers.

To our knowledge, our résumé experiment is one of the first studies to measure employment discrimination in the form of coworker discomfort and salary recommendations among job applicants with transgender-related work experience. Our results may also provide insight into how stigma and discrimination may operate in the workplace among individuals with transgender-related work experience. Our findings suggest a meaningful proportion of employers may perceive job applicants with transgender-related work experience listed on their résumé as transgender, regardless of their actual gender identity, and that individuals who work in gender-minority serving organizations are at risk of experiencing stigma or stigma-byassociation. It is possible that these individuals may encounter subtle forms of discrimination. This discrimination may put both individuals who work in transgender-related organizations and gender-minority individuals at risk for health-related consequences of any resulting workplace discrimination (Dhanani, Beus, \& Joseph, 2018).

Minority and psychological stress are also mechanisms linking employment discrimination to health inequities (Meyer, 2003; Pitoňák, 2017). Such discrimination can have profound effects as GM people are more than twice as likely to live in poverty compared to cisgender individuals (James et al., 2016), which may contribute to limited insurance coverage and access to healthcare (James et al., 2016). Studies have shown LGBT individuals who experience discrimination are at an increased risk of disease including substance abuse, cardiovascular disease and HIV infection and progression (Denton, Rostosky, \& Danner, 2014; Frost, Lehavot, \& Meyer, 2015). Despite efforts to eliminate these inequities through health interventions, these inequities are often sustained through social factors such as socioeconomic status and stigma (Meyer, 2003; Pitoňák, 2017). 


\section{Courtesy Stigma for Counselors}

\section{Results in Context}

Recent greater emphasis on diversity and inclusion in professional settings and increasing social acceptance of SGM individuals may help to suppress overt forms of discrimination in the workplace, proliferating more subtle, but still detrimental, mechanisms of employment discrimination among SGM people (Cortina, 2008; Cortina, Kabat-Farr, Leskinen, Huerta, \& Magley, 2013; Jones, Peddie, Gilrane, King, \& Gray, 2016). Our findings are consistent with other studies investigating employment discrimination, in that while no evidence of formal discrimination was found, evidence of informal discrimination was uncovered. In an experimental study of formal and informal labor market discrimination among gay job applicants (Hebl, Foster, Mannix, \& Dovidio, 2002), no evidence of formal discrimination (being denied permission to complete a job application, being denied access to restrooms, and not receiving a callback) was found. However, when the job applicant was portrayed as gay, interactions between the employer and the applicant were significantly shorter, had significantly lower word counts and were significantly more likely to be perceived as a negative experience by the job applicant, indicating informal discrimination. Also, our results support findings from previous studies that voluntary associates of stigmatized individuals are often perceived as being members of the stigmatized group themselves (Sigelman et al., 1991). Our results suggest that stigma operating through informal workplace discrimination (i.e., operating as coworker discomfort) can impact job applicants regardless of their actual gender identity. That is, our results support past research on stigma by association and extend them to GM individuals and allied health and human service professionals.

\section{Strengths and Limitations}

The strengths of this study include its experimental design and the use of a résumé format validated in prior research (Pedulla, 2014). This study also has limitations. While Study 1 was conducted in Durham, North Carolina, which is in the progressive Research Triangle region of the state, Study 2 did not assess region of the country or location of the participant. The incentives, sampling, and mode of both studies were different: Both studies may not generalize broadly; however, online panels have promise for providing generalizable results of experiments (Jeong et al., 2018). We did not recruit camp employers or indicate a camp or human services job in the experiment; this could have altered our findings. Future studies should assess moderation by gender of the employer, differences in results by race and regional differences. While our experimental design has good internal validity, rating résumés at a pride festival or online may not be the same as doing so as a hiring manager. 


\section{Courtesy Stigma for Counselors}

\section{Practice Implications and Conclusion}

There are also important practical implications for hiring managers at youth camps. First, managers should be aware of the potential role of bias in hiring decisions and maximize diversity in the hiring or interview team. Second, personnel involved in the interview and hiring process should consider the use of standardized or structured interview processes to rate candidates, as these can help reduce bias by collecting the same information from all candidates and focusing personnel on relevant experiences (Bragger, Kutcher, Morgan, \& Firth, 2002; de Kock \& Hauptfleisch, 2018; Derous, Buijsrogge, Roulin, \& Duyck, 2016). Third, the overall organizational culture's inclusiveness towards differences can spill over into hiring (Boehm, Kunze, \& Bruch, 2014).

Our research does not directly assess how individuals can mitigate forms of bias in the job application process. Existing literature suggests some success may come from highlighting attributes that contrast with the negative stereotype (Bendick, Jackson, \& Romero, 1996); however, future research is warranted. Future research should consider other forms of employment discrimination against GM people as well as personal and organizational strategies for mitigating such discrimination.

In conclusion, in our experimental résumé study, transgender-related work experience predicted perceptions of job applicants' gender identity, and applicants with transgender-related work history were rated by participants in Study 2 to be statistically significantly more likely to make their coworkers feel uncomfortable than applicants without transgender-related work experience. Discrimination by association and informal discrimination is of concern both for GM individuals and allied professionals and coworkers. Camp personnel involved in hiring should be aware of potential discrimination in the hiring process.

\section{Acknowledgements}

This research was supported in part by East Carolina University. Our thanks to the ECU LGBT Health Promotion Team members who braved the heat at the 2016 North Carolina Pride Festival to collect these data: Kelly Abrams, Joseph Chukwu, Nicholas Conde-Palmer, Megan DeMarco, Sarah Hackman, Kurtis Kozel, Jaleel Kuteh, Imani Ricks, Molly Robinson, Samantha Wooten, and Kristyn Wynn. Leslie Cofie provided helpful feedback on the manuscript. The authors declare that they have no conflict of interest. 


\section{Courtesy Stigma for Counselors}

\section{References}

Bardales, N. (2013). Finding a job in "a beard and a dress": Evaluating the effectiveness of transgender anti-discrimination laws. (Unpublished bachelor's thesis). University of California, San Diego. Retrieved from https://polisci.ucsd.edu/_files/undergrad/Thesis\%202013\%20Finding\%20a \%20Job\%20in\%20a\%20Beard\%20and\%20a\%20Dress\%20Evaluating\%20the\%20Effectiveness \%20of\%20Transgender\%20Antidiscrimination\%20Laws.pdf

Bemak, F., \& Chung, R. C.-Y. (2005). Advocacy as a critical role for urban school counselors: Working toward equity and social justice. Professional School Counseling, 8(3), 196-202.

Bendick, M., Jr., Jackson, C. W., \& Romero, J. H. (1996). Employment discrimination against older workers: an experimental study of hiring practices. Journal of Aging and Social Policy, 8(4), 2546. doi:10.1300/J031v08n04_03

Boehm, S. A., Kunze, F., \& Bruch, H. (2014). Spotlight on age-diversity climate: The impact of ageinclusive HR practices on firm-level outcomes. Personnel Psychology, 67(3), 667-704. doi:10.1111/peps. 12047

Bos, A. E., Pryor, J. B., Reeder, G. D., \& Stutterheim, S. E. (2013). Stigma: Advances in theory and research. Basic and Applied Social Psychology, 35(1), 1-9. doi:10.1080/01973533.2012.746147

Bragger, J. D., Kutcher, E., Morgan, J., \& Firth, P. (2002). The effects of the structured interview on reducing biases against pregnant job applicants. Sex Roles, 46(7-8), 215-226. doi:10.1023/A:1019967231059

Buck, D. M., Plant, E. A., Ratcliff, J., Zielaskowski, K., \& Boerner, P. (2013). Concern over the misidentification of sexual orientation: Social contagion and the avoidance of sexual minorities. Journal of Personality and Social Psychology, 105(6), 941. doi:10.1037/a0034145

Cortina, L. M. (2008). Unseen injustice: Incivility as modern discrimination in organizations. Academy of Management Review, 33(1), 55-75. doi:10.5465/amr.2008.27745097

Cortina, L. M., Kabat-Farr, D., Leskinen, E. A., Huerta, M., \& Magley, V. J. (2013). Selective incivility as modern discrimination in organizations: Evidence and impact. Journal of management, 39(6), 1579-1605. doi:10.1177/0149206311418835

de Kock, F. S., \& Hauptfleisch, D. B. (2018). Reducing racial similarity bias in interviews by increasing structure: A quasi-experiment using multilevel analysis. International Perspectives in Psychology: Research, Practice, Consultation, 73), 137. doi:10.1037/ipp0000091

DeGraaf, D., \& Glover, J. (2003). Long-Term impacts of working at an organized camp for seasonal staff. Journal of Park \& Recreation Administration, 21(1), 1-20.

Denton, F. N., Rostosky, S. S., \& Danner, F. (2014). Stigma-related stressors, coping self-efficacy, and physical health in lesbian, gay, and bisexual individuals. J Couns Psychol, 61(3), 383-391. doi:10.1037/a0036707 
Journal of Youth Development | http://jyd.pitt.edu/ | Vol. 14 Issue 4 DOI 10.5195/jyd.2019.829

\section{Courtesy Stigma for Counselors}

Derous, E., Buijsrogge, A., Roulin, N., \& Duyck, W. (2016). Why your stigma isn't hired: A dual-process framework of interview bias. Human Resource Management Review, 26(2), 90-111. doi:10.1016/j.hrmr.2015.09.006

Dhanani, L. Y., Beus, J. M., \& Joseph, D. L. (2018). Workplace discrimination: A meta-analytic extension, critique, and future research agenda. Personnel Psychology, 71(2), 147-179. doi:10.1111/peps.12254

Digby, J. K., \& Ferrari, T. M. (2007). Camp counseling and the development and transfer of workforce skills: The perspective of Ohio 4-H camp counselor alumni. Journal of Youth Development, 2(2), 103-122. doi:10.5195/jyd.2007.349

Duerden, M. D., Witt, P., Garst, B., Bialeschki, D., Schwarzlose, T., \& Norton, K. (2014). The impact of camp employment on the workforce development of emerging adults. Journal of Park \& Recreation Administration, 32(1).

Fenton, L. (2018). 'You can see their minds grow': identity development of LGBTQ youth at a residential wilderness camp. Leisure/Loisir, 42(3), 347-361. doi:10.1080/14927713.2018.1535276

Fouad, N., Gerstein, L., \& Toporek, R. L. (2006). Social justice and counseling psychology in context. In R. L. Toporek, L. Gerstein, N. Fouad, G. Roysircar, \& T. Israel (Eds.), Handbook for social justice in counseling psychology: Leadership, vision, and action (pp. 1-16). Thousand Oaks, CA: Sage.

Fredriksen-Goldsen, K. I., Simoni, J. M., Kim, H. J., Lehavot, K., Walters, K. L., Yang, J., . . Muraco, A. (2014). The health equity promotion model: Reconceptualization of lesbian, gay, bisexual, and transgender (LGBT) health disparities. American Journal of Orthopsychiatry, 84(6), 653-663. doi: $10.1037 /$ ort0000030

Frost, D. M., Lehavot, K., \& Meyer, I. H. (2015). Minority stress and physical health among sexual minority individuals. Journal of Behavioral Medicine, 38(1), 1-8. doi:10.1007/s10865-013-9523-8

Garst, B. A., Franz, N. K., Baughman, S., Smith, C., \& Peters, B. (2009). Growing Without Limitations:" Transformation Among Young Adult Camp Staff. Journal of Youth Development, 4(1), 21-34. doi:10.5195/jyd.2009.272

Gillard, A., Buzuvis, E. E., \& Bialeschki, M. D. (2014). Supporting transgender and gender nonconforming youth at summer camp. Journal of Park \& Recreation Administration, 32(3).

Gillig, T. K., Miller, L. C., \& Cox, C. M. (2019). "She finally smiles... for real": Reducing depressive symptoms and bolstering resilience through a camp intervention for LGBTQ youth. Journal of Homosexuality, 66(3), 368-388. doi:10.1080/00918369.2017.1411693

Goffman, E. (1986). Stigma: Notes on the management of spoiled identity. New York, NY: Simon \& Schuster.

Goldstein, S. B. (2017). Stigma and stigma by association in perceptions of straight allies. Journal of LGBT Youth, 14(4), 345-358. doi:10.1080/19361653.2017.1326867 


\section{Courtesy Stigma for Counselors}

Green, E. L., Benner, K., \& Pear, R. (2018). 'Transgender' could be defined out of existenced under Trump administration. Retrieved from https://www.nytimes.com/2018/10/21/us/politics/transgender-trump-administration-sexdefinition.html

Gurwitz, S. B., \& Marcus, M. (1978). Effects of anticipated interaction, sex, and homosexual stereotypes on first impressions. Journal of Applied Social Psychology, 8(1), 47-56. doi:10.1111/j.15591816.1978.tb00764.x

Hebl, M. R., Foster, J. B., Mannix, L. M., \& Dovidio, J. F. (2002). Formal and interpersonal discrimination: A field study of bias toward homosexual applicants. Personality and Social Psychology Bulletin, 28(6), 815-825. doi:10.1177/0146167202289010

Hebl, M. R., \& Mannix, L. M. (2003). The weight of obesity in evaluating others: A mere proximity effect. Personality and Social Psychology Bulletin, 29(1), 28-38. doi:10.1177/0146167202238369

Heider, F. (1958). The psychology of interpersonal relations. Hillsdale, NJ: Lawrence Erlbaum Associates. doi:10.1037/10628-000

Institute of Medicine. (2011). The health of lesbian, gay, bisexual, and transgender people: Building a foundation for better understanding. Washington, DC: National Academies Press.

James, S. E., Herman, J. L., Rankin, S., Keisling, M., Mottet, L., \& Anafi, M. (2016). The report of the 2015 U.S. transgender survey. Retrieved from http://www.transequality.org/sites/default/files/docs/usts/USTS\%20Full\%20Report\%20\%20FINAL\%201.6.17.pdf

Jeong, M., Zhang, D., Morgan, J. C., Ross, J. C., Osman, A., Boynton, M. H., . . Brewer, N. T. (2018). Similarities and differences in tobacco control research findings from convenience and probability samples. Annals of Behavioral Medicine. doi:10.1093/abm/kay059

Jones, K. P., Peddie, C. I., Gilrane, V. L., King, E. B., \& Gray, A. L. (2016). Not so subtle: A meta-analytic investigation of the correlates of subtle and overt discrimination. Journal of management, 42(6), 1588-1613. doi:10.1177/0149206313506466

Kulik, C. T., Bainbridge, H. T., \& Cregan, C. (2008). Known by the company we keep: Stigma-byassociation effects in the workplace. Academy of Management Review, 33(1), 216-230. doi: $10.2307 / 20159384$

Lekus, I. K. (2001). Health care, the AIDS crisis, and the politics of community: The North Carolina Lesbian and Gay Health Project, 1982-1996. In A. M. Black (Ed.), Modern American Queer History (pp. 227-252). Philadelphia, PA: Temple University Press.

Link, B. G., \& Phelan, J. C. (2001). Conceptualizing stigma. Annual Review of Sociology, 27, 363-385. doi:10.1146/annurev.soc.27.1.363 


\section{Courtesy Stigma for Counselors}

Mail, P. D., \& Lear, W. J. (2006). The role of public health in lesbian, gay, bisexual, and transgender health. In M. D. Shankle (Ed.), Handbook of lesbian, gay, bisexual, \& transgender public health: A practitioner's guide to service (pp. 11-32). New York: Harrington Park Press.

Make the Road New York. (2010). Transgender need not apply: A report on gender identity job discrimination. Retrieved from http://digitalcommons.ilr.cornell.edu/cgi/viewcontent.cgi?article=1020\&context=institutes

Malek, N., Harrison, S. J., \& John-Baptiste, A. (2017). Case 8: Camp fYrefly. Western Public Health Casebooks, 20171), 14. Retrieved from https://ir.lib.uwo.ca/westernpublichealthcases/vol2017/iss1/14/

Meyer, I. H. (2003). Prejudice, social stress, and mental health in lesbian, gay, and bisexual populations: conceptual issues and research evidence. Psychol Bull, 129(5), 674-697. doi:10.1037/00332909.129.5.674

Neuberg, S. L., Smith, D. M., Hoffman, J. C., \& Russell, F. J. (1994). When we observe stigmatized and "normal" individuals interacting: Stigma by association. Personality and Social Psychology Bulletin, 20(2), 196-209. doi:10.1177/0146167294202007

Pedulla, D. S. (2014). The positive consequences of negative stereotypes: Race, sexual orientation, and the job application process. Social Psychology Quarterly, 77(1), 75-94. doi:10.1177/0190272513506229

Phillips, R., Benoit, C., Hallgrimsdottir, H., \& Vallance, K. (2012). Courtesy stigma: A hidden health concern among front-line service providers to sex workers. Sociology of Health and IIIness, 34(5), 681-696. doi:10.1111/j.1467-9566.2011.01410.x

Pitoňák, M. (2017). Mental health in non-heterosexuals: Minority stress theory and related explanation frameworks review. Mental Health \& Prevention, 5, 63-73. doi:10.1016/j.mhp.2016.10.002

QORDS. (2019). About QORDS. Retrieved from https://qords.org/about/

Rainey, T., \& Imse, E. E. (2015). Qualified and transgender: a report on the results of resume testing for employment discrimination based on gender identity. Retrieved from http://ohr.dc.gov/sites/default/files/dc/sites/ohr/publication/attachments/QualifiedAndTransgend er_FullReport_1.pdf

Sack, W. H., Seidler, J., \& Thomas, S. (1976). The children of imprisoned parents: a psychosocial exploration. American Journal of Orthopsychiatry, 46(4), 618-628. doi:10.1111/j.19390025.1976.tb00960.x

Sigelman, C. K., Howell, J. L., Cornell, D. P., Cutright, J. D., \& Dewey, J. C. (1991). Courtesy stigma: the social implications of associating with a gay person. Journal of Social Psychology, 131(1), 45-56. doi:10.1080/00224545.1991.9713823 


\section{Courtesy Stigma for Counselors}

Swim, J. K., Ferguson, M. J., \& Hyers, L. L. (1999). Avoiding stigma by association: Subtle prejudice against lesbians in the form of social distancing. Basic and Applied Social Psychology, 21(1), 6168. doi:10.1207/s15324834basp2101_6

Teich, N. M. (2019). Camp Aranu'tiq: Notes from the First Camp for Transgender and Gender Variant Youth. In A. I. Lev \& A. R. Gottlieb (Eds.), Families in transition: Parenting gender diverse children, adolescents, and young adults. New York, NY: Harrington Park Press.

Vincke, J., \& van Heeringen, K. (2004). Summer holiday camps for gay and lesbian young adults: An evaluation of their impact on social support and mental well-being. Journal of Homosexuality, 47(2), 33-46. doi:10.1300/J082v47n02_02

White Hughto, J. M., Reisner, S. L., \& Pachankis, J. E. (2015). Transgender stigma and health: A critical review of stigma determinants, mechanisms, and interventions. Soc Sci Med, 147, 222-231. doi:10.1016/j.socscimed.2015.11.010 